\title{
CULTURAL ENCOUNTER IN THE MORTUARY LANDSCAPE OF A TIWANAKU COLONY, MOQUEGUA, PERU (AD 650-1100)
}

\author{
Sarah I. Baitzel
}

\begin{abstract}
Archaeological studies of culture contact often presuppose culture change. Contact that did not result in culture change is difficult to identify archaeologically, but it merits our attention for understanding how and why change failed to materialize in the wake of cultural encounter. In this paper, I examine the occurrence of contact without change on the frontier of the south-central Andean Tiwanaku state (AD 400-1100). Tiwanaku settlers who colonized the uninhabited middle Moquegua valley in the seventh century $A D$ shared a mortuary landscape with coastal sojourners at the site of Omo M10, even though their interactions were otherwise limited. Complex regional histories and divergent economic interests explain why contact between highland and coastal groups was confined to mortuary rituals during the initial stage of contact, following a Tiwanaku pattern in Moquegua of ritualizing culture contact. Later generations of Tiwanaku colonists may have reinitiated contact with coastal communities for access to marine resources, and accepting foreigners into their community. This case study presents a framework for identifying culture contact without culture change. It demonstrates the utility of regional histories and careful contextual analysis for hypothesizing the nature and consequences of cultural encounters that did not follow expected trajectories of change.
\end{abstract}

Los estudios arqueológicos sobre contacto cultural frecuentemente presuponen la ocurrencia de un cambio cultural. Los contactos que no resultan en un cambio cultural son difíciles de identificar arqueológicamente. Sin embargo, este tipo de contacto merece nuestra atención para esclarecer cómo y por qué no llegó a realizarse un cambio como resultado del encuentro cultural. En este trabajo se examina un ejemplo de contacto sin cambios en las fronteras del estado Tiwanaku (400-1100 dC) de los Andes centro-meridionales. Los colonos Tiwanaku ocuparon las zonas deshabitadas del sector medio del Valle de Moquegua en el siglo siete dC. Estos colonos compartieron el paisaje cultural mortuorio con viajeros costeños en el sitio de Omo M10, a pesar de que las interacciones entre los grupos fueron limitadas en otros aspectos. Complejas historias regionales e intereses económicos divergentes explican por qué las interacciones entre los grupos de la sierra y de la costa estuvieron limitadas a los rituales mortuorios durante las etapas iniciales de contacto, siguiendo un patrón típico de Tiwanaku en Moquegua que consiste en ritualizar el contacto cultural. Las posteriores generaciones de colonos Tiwanaku pudieron haber reiniciado el contacto con las comunidades costeras para acceder a los recursos marinos, con el resultado de aceptar grupos foráneos dentro de sus comunidades. Este caso de estudio presenta un marco teórico para identificar el contacto cultural sin cambio cultural. Se muestra la utilidad de las historias regionales y de un cuidadoso análisis de los contextos para generar hipótesis acerca de la naturaleza y las consecuencias de los encuentros culturales que no siguieron las trayectorias de cambio esperadas.

\section{The Archaeology of Contact, Colonization, and Culture Change}

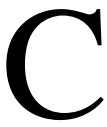
ulture contact shaped life in the borderlands of ancient states. Colonialism, conquest, and interregional trade transformed communities in frontier settings, leading to acculturation, hybridization, or ethnogenesis (Lightfoot 1995; Voss 2008). Yet, to study culture contact as diachronic culture change precludes us from identifying situations in which contact did not have a lasting material impact. To identify such scenarios of contact, we must first ascertain that contact occurred, i.e., establish spatial and temporal overlap of different culture groups independent of objects, people, or practices that moved between them. Once contemporaneity is established, we can venture to theorize the

Sarah I. Baitzel — Department of Anthropology, Washington University in St. Louis, One Brookings Drive 1114, St. Louis, MO 63130 (sbaitzel@wustl.edu)

Latin American Antiquity 29(3), 2018, pp. 421-438

Copyright (C) 2018 by the Society for American Archaeology doi:10.1017/laq.2018.25 
reasons and processes that led to culture contact and that stymied substantial culture change. This requires close attention to local histories and the circumstances of contact. Our abilities to theorize contact-sans-change is limited by the absence of data. Nevertheless, it provides important insights about the range of dynamics that shaped cultural encounters.

In the ancient Andes, culture contact was embedded in enduring structures of exchange and mobility (Murra 1972; Nuñez and Dillehay 1995; Rostworowski de Diez Canseco 1975). It resulted in ethnogenesis, acculturation, or isolationism, especially under the auspices of state expansion and prehispanic colonialism (Buikstra 2005; D'Altroy 2002). The south-central highland Andean Tiwanaku state (AD 400-1100) colonized the western Andean lowlands, seeking out limited ritualized interactions with other regional powers along its periphery. At one of these locations, the middle Moquegua valley, where Tiwanaku colonists settled abandoned territory, recent mortuary excavations at the site of Omo M10 documented a culturally distinct cemetery within the Tiwanaku-style mortuary landscape of the site. This cemetery features mortuary traditions of coastal origins, yet it dates to the Tiwanaku occupation of Omo M10, whose highland assemblages lack foreign influence. I propose that culture contact between the two groups, neither of whom was native to the valley, was shaped early on by mortuary rituals, while economic interactions were limited. Although initial culture contact between coastal and highlands groups at Omo M10 did not lead to change, more substantial contact was reinitiated later in the Middle Horizon period, finding expression in burials as well as nonmortuary contexts.

\section{Coexistence as Evidence of Contact}

Border regions of early states are principal sites of culture contact, often embedded in asymmetrical webs of inequality, hierarchy, and resistance (Lightfoot and Martinez 1995; Parker and Rodseth 2005). Among the peripheries, boundaries, and frontiers discussed by archaeologists, colonies present a particularly intriguing type of border. Discontiguous with their homeland, colonies are "implanted settlements" established in inhabited or uninhabited foreign territory
(Stein 2005:10). As such, colonists find themselves beyond the borders of their homeland, and contact with other cultures becomes a necessity that ultimately reshapes identities and practices (Stein 2005:13).

Archaeological models of culture contact arose in the 1990s to bridge the prehistoric and historical archaeologies of colonialism (Lightfoot 1995; Silliman 2005). They characterized interactions between colonizers and local populations as unequal and hierarchical, while also highlighting the power of local agents (Gosden 2004; Lyons and Papadopoulous 2002). As archaeologists, we study culture contact as culture change, i.e., assuming that culture contact inadvertently led to recognizable changes in material assemblages. These changes have been alternately termed acculturation, creolization, hybridity, and ethnogenesis (Gosden 2004; Mullins and Paynter 2000; Stockhammer 2012; Voss 2008). The diachronicity of archaeological data readily offers a long-term perspective from which to assess the effect of culture contact.

Here I challenge two assumptions that underlie archaeological approaches to culture contact. First, material assemblages of proximate culture groups that come to share certain characteristics over time attest to culture contact; so do synchronic, neighboring assemblages that show no influence. Their spatiotemporal overlap can be considered indicative of contact or at least of the awareness of existence between culture groups. Therefore, to entertain the idea of culture contact, we must first prove spatiotemporal coexistence. Secondly, even if coexistence can be demonstrated, culture contact may not have resulted in acculturated, hybridized, or new cultural identities. In this case we must nonetheless explain the nature of contact and the lack of change. Why did culture contact not have longlasting effects on one or more groups involved? Is culture change always a necessary outcome in the case of colonies, where prolonged contact with other cultures and increased distance from the homeland intensify contact? When does culture change occur as a result of contact, and when does it not?

To address these questions, I consider a somewhat different scenario of colonization than is typical in culture contact studies. The middle 
Moquegua valley, the backdrop for this case study, was briefly uninhabited prior to colonization by Tiwanaku settlers in the seventh century AD. Compared to traditional studies of colonialism and culture contact, colonization of uninhabited regions has received little attention, aside from the scholarship on the expansion of early modern humans across the globe, and historicalperiod explorations (Rockman and Steele 2003). Colonization of "virgin" territories may also apply to temporarily uninhabited areas that were abandoned but remained part of the broader cognitive landscape (Barker 2000; Rosen 2000). Settler colonization of "virgin" territory depends on the demographic structure and goals of the colonizing project (Murray 2004). In contrast to trade enclaves and military outposts, which presume the presence of a local indigenous population for exchange or subjugation (Alcock 2005; Spence 2005; Stein 2002), settler colonies are self-reproducing, self-reliant, and must be adaptive to their new environment to succeed (Murray 2004:6). The sheer size of settler colonies alone presents an advantage for negotiating interactions with neighboring groups, even without military or infrastructural support from the homeland. From their new location, colonizers build up exchange networks that form the intersections and entanglements essential to colonialism (Silliman 2005:61). Among the tasks settler colonists face in their new location is the disposal of the dead. Local burial present foremost a practical choice over the repatriation of remains.

\section{Culture Contact and the Dead in the Ancient Andes}

Cemeteries are an enduring representation of the settler colony in the region, especially when continued interaction with the dead promotes the eventual return of the living. Mortuary landscapes communicate relationships within and between communities (Beck 1995; Chapman et al. 1981; Goldstein 1981). Physical distance between settler cemeteries and foreign ancestral landscapes may signal social distance, fear, or adversity. Placing the dead near the burial grounds or residences of previous inhabitants of the area may reflect dominance over or affinity with other culture groups that are long gone or have moved away. Settler cemeteries thus initiate the ancestral landscapes of future generations of colonists and contribute to the legitimization of the colonial presence in the region (van Dommelen 2005). Once established, colonial cemeteries become permanent features that invite or ward off contact for generations to come.

In the ancient Andes, culture contact was fundamental early on for exchanging vital resources across an ecologically diverse environment (Nuñez and Dillehay 1995). Movement of resources along the altitudinal zones of the Andean highlands to the Pacific coast and Amazon occurred in the context of interaction and exchange between different culture groups. During later prehispanic times in the southern Andes, these intercultural interactions were supplanted by a system of "vertical control" (Murra 1972), in which highland polities directly acquired resources by establishing colonies in different ecological zones, thereby eliminating interaction with other groups.

Discussions of prehispanic Andean culture contact are complicated by a regional disciplinary tendency to label culture groups, "ethnic groups," and cultural identity, "ethnicity" (Stovel 2013). Here I use culture "as an analytical tool to describe synchronic moments of comparatively different behavior and beliefs reflected in multiple material aspects" (Stovel 2013:4) to distinguish between social groups without making inferences about the nature of their relationship. Mortuary practices contribute to the behaviors and beliefs used to define culture and cultural boundaries and occasionally feature in discussions of culture contact (e.g., Lozada and Buikstra 2005; Sharratt 2017). Attributes such as tomb structure, body orientation, and position are strong signifiers of deeply rooted cultural beliefs about death and of cultural differences (Carr 1995:190). The degree to which mortuary ritual change can be indicative of culture contact and change (Buzon 2006; Emerson and Hargrave 2000). Among the most visible foreign cultural influences that infiltrate mortuary ritual is the use of exotics as grave offerings, where they may reflect status or extended social network (Peebles and Kus 1977) or signal the deceased's cultural origins (Cool 2010).

In the ancient Andes, scarcity of exotics in burials attests to the internal focus of mortuary 
rituals, where interactions between the living and the dead were believed to benefit the community (Dillehay 1995; Lau 2002; Shimada and Fitzsimmons 2015). When included, exotics are understood to mark the status and far-reaching connections of the deceased and their social group (Castillo Butters et al. 2012; Goldstein 2000). The presence of exotics alone establishes the existence of culture contact (or down-the-line economic exchange), but more profound changes in burial disposition or location can provide greater insight into the nature and scope of contact. For example, the visibility and location of funerary structures have been associated with territoriality and place-making vis-à-vis other foreigners or neighbors (Frey and de la Vega 2005; Mantha 2009), while body position and offering assemblages can be useful indicators for identifying individuals or groups of different cultural origins in a new place (Salazar 2007; Turner et al. 2009).

Cemeteries are not usually considered sites where culture contact finds expression, yet they can materialize contact in several ways. If synchronicity can be established using relative or absolute dating methods, we can assess the degree to which colonists incorporated symbols of culture contact in their funerary practicesfrom the inclusion of foreign objects to the position of human remains, from burial architecture to cemetery location. Heirlooms or curated objects used as grave goods can complicate the relative dating of burials. In the absence of clear stratigraphic relationship between mortuary contexts, radiocarbon dates are the most reliable, yet pricey, dating method. Radiocarbon dates from a select number of burial contexts may prove advantageous for comparing individual burials or pinpointing specific moments of interaction.

\section{Evolving Cultural Landscapes of the Moquegua Valley, Peru}

To understand the complexity and intricacies of the cultural and mortuary landscapes at the site of Omo M10 during the Middle Horizon, the time and place in question here, we must account for the different occupational histories that converged in the Moquegua valley around this period. The Osmore drainage in the south- central Andes of modern Peru was recurrently colonized over the last 10,000 years, from the initial arrival of maritime populations and highlandadapted hunter-gatherers (Aldenderfer 1990), colonial projects under the Wari, Tiwanaku, and Inca states, to Spanish colonial occupation (Rice 2013). The middle Moquegua valley $(1,100-1,400 \mathrm{~m}$ asl) forms the central portion of the drainage. It is a temperate desert oasis with perennial agricultural usage through seasonal floodplain and canal irrigation (Figure 1). Over three decades of intensive archaeological research have documented the continuous occupation of the middle valley beginning in the Middle Formative period (1500 BC), when Huaracane populations inhabited small dispersed villages and subsisted on floodplain agriculture (Goldstein 2000:344). They participated in longdistance exchange networks (Feldman 1990:230; Goldstein 2000:354); ceramic assemblages and tumuli associate the Huaracane population with the Alto Ramirez tradition to the south (Agüero and Uribe 2015; Romero Guevara et al. 2004). Boot tombs that came into fashion at the end of the Formative period attest to greater social stratification specific to the Moquegua valley (Goldstein 2000:352). Baskets and beads made from stone, bone, and copper sheets are among boot tombs and tumuli grave offerings; no intact ceramic vessels have been found in Huaracane burials (Goldstein 2000:351). The Huaracane occupation of the middle Moquegua valley ended after the fourth century AD (Goldstein 2000:Table 3). Magilligan and Goldstein (2001:443) have proposed that around AD 700, an El Niño Southern Oscillation event destroyed Huaracane agricultural fields, forcing indigenous groups to abandon the middle valley and move to higher elevations where they resided as late as the ninth century AD (Costion 2013:566). We currently lack a clear understanding of the chronology and causes of the Huaracane abandonment of the middle Moquegua valley.

At the end of the seventh century AD, highland settlers arrived in Moquegua from the Tiwanaku state, centered $250 \mathrm{~km}$ to the east in the Andean altiplano $(3,800 \mathrm{~m}$ asl). They established substantial towns along the edges of the valley, supported by extensive canal irrigation systems (Goldstein 2005; Williams 1997). 


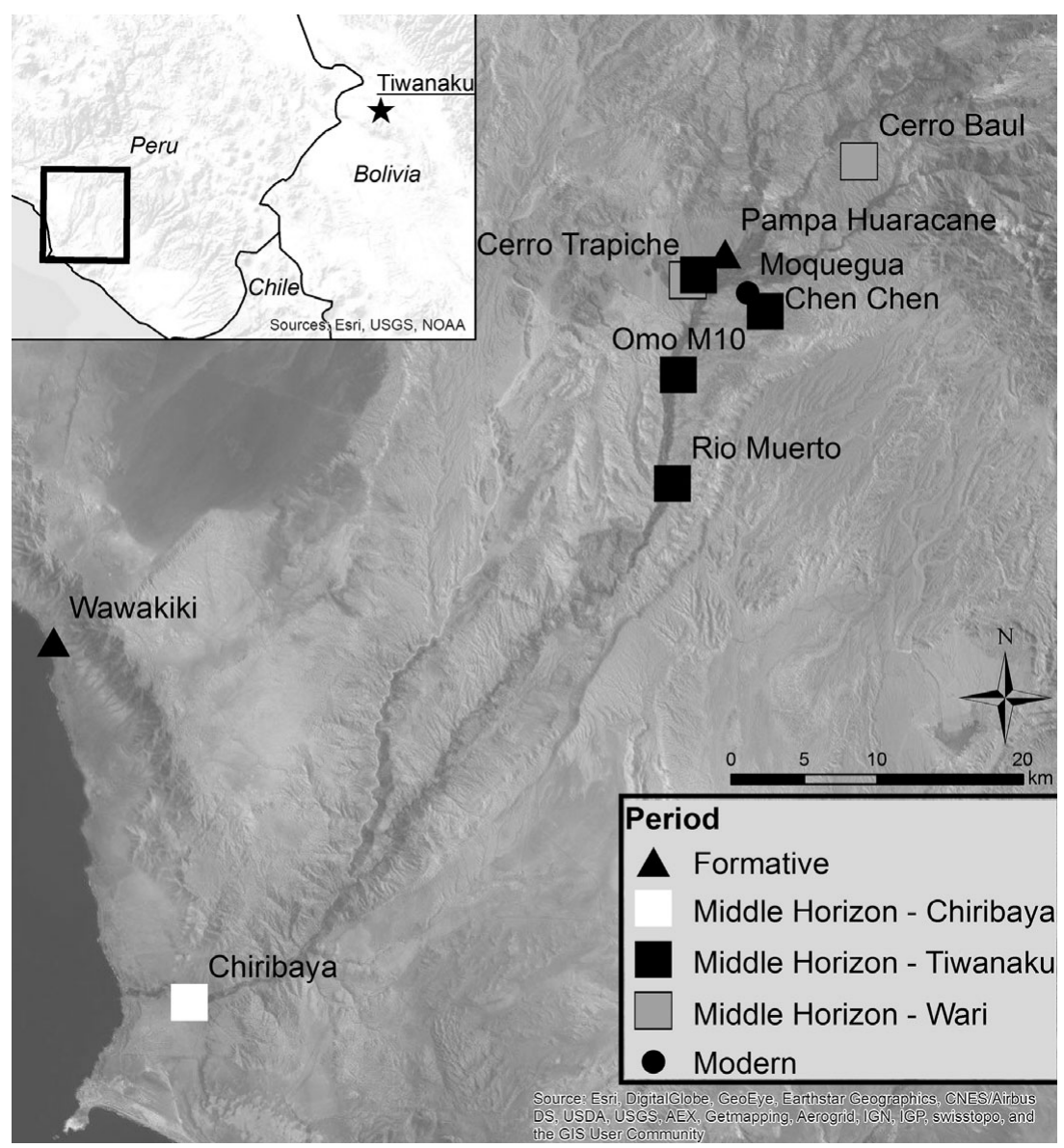

Figure 1. Map of Moquegua Valley and location of sites mentioned in text (Map by S. Baitzel using GoogleEarth source data).

Elsewhere in the southern Andes, Tiwanaku traded with the San Pedro de Atacama oasis (Stovel 2001; Torres-Rouff 2008) and interacted with local populations in the eastern lowland valley of Cochabamba (Anderson 2013). The Tiwanaku colonies of the Moquegua valley $(1,100-1,400 \mathrm{~m}$ asl) were by far the most populous settlements of highlanders outside the altiplano, numbering in the thousands and occupying 78 ha in the middle Moquegua valley (Goldstein 2013:Table 4.3). The importation of highland goods, people, and cultural practices to the valley sustained Tiwanaku identity over multiple generations, as seen in body modification traditions and domestic assemblages, construction of highland-style monumental temple complexes, and large cemeteries. Opinions differ about the role of the Tiwanaku state in colonizing the Moquegua valley. Goldstein $(2005,2009,2013,2015)$ highlights the culturally diverse, autonomous, diasporic nature of Tiwanaku colonies and argues that Tiwanaku presence in Moquegua foreshadows the multiethnic archipelagos of the Late Intermediate Period. Nevertheless, the construction of a ceremonial complex at the site of Omo M10 and reorientation of domestic space mirror processes taking place in the Tiwanaku capital that could reflect state-organized influence especially during the later Middle Horizon (Goldstein 1989; Owen 2005:45).

Breaking from the Formative-period burial tradition of tumuli and boot tombs, bounded highland-style cemeteries transformed the mortuary landscape of the Moquegua valley. Tiwanaku cemeteries had below-ground tombs 
that accommodated individual funerary bundles and small offering sets of serving wares, jewelry, tools, and ritual paraphernalia. A handful of Wari-style vessels found among the more than 5,000 excavated Tiwanaku-style tombs in Moquegua (Garcia Marquez 1990; Sharratt 2011) underscore the limited and ritualized nature of interactions between Wari and Tiwanaku settlers in Moquegua (Williams 2013:37). The absence of evidence for contact between Tiwanaku and Huaracane populations in mortuary and non-mortuary contexts is striking, and lends support to Goldstein and Magilligan's hypothesis that this area of the valley was abandoned by the time the Tiwanaku arrived.

It is noteworthy that the Pacific coast did not present an economic or ideological incentive in the westward expansion of Tiwanaku. To date no marine resources have been documented in the material and iconographic record of altiplano Tiwanaku sites. In Moquegua, the colonial Tiwanaku ceremonial complex at the Omo M10 site contained symbolically complementary offerings of highland and marine fauna (Goldstein 2005:297). Initially low marine fauna frequencies in residential middens at Omo M10 increased toward the terminal occupation (Goldstein 1989:Table 11), as did the use of Olivela peruvianis shells for bead production (Goldstein 2005:201). Rising proportions of marine fauna at Tiwanaku sites in Moquegua suggests a growing popularity of coastal resources among highlander descendants. Survey of the lower Osmore drainage (of which the Moquegua river forms the midelevation section) revealed no Tiwanaku settlements dating to the Middle Horizon (Owen 2005:54).

Meanwhile, coastal occupation dating to the Late Formative/Early Middle Horizon periodcontemporaneous with the earliest Tiwanaku settlers in the middle valley-took the form of small settlements in the littoral zone whose occupants relied on a mixed subsistence strategy of marine resource exploitation and agriculture (Bawden 1990:197). Near the coast, the site of Wawakiki (Figure 1) exhibited shallow burial pits containing flexed individuals positioned on their sides, randomly aligned. The remains were wrapped in coarse textiles and layers of reed mats (Bawden 1990:196). ${ }^{1}$ After AD 900, coastal Chiribaya populations established a dual complementary system of marine economies and agriculture; this included the adaptation of Tiwanaku-style elements into the ceramic assemblage and into individual and communal tombs (Lozada and Buikstra 2002). Marine-associated grave offerings, such as fishhooks, reflect the importance of ocean resources to Chiribaya populations (Jessup 1991:9).

At the end of the seventh century AD, the recently abandoned middle Moquegua valley presented a land of opportunity for Tiwanaku highland populations. The region was perhaps already known to them through longstanding seasonal exchange interactions between the highlands and lowlands that were facilitated by caravan routes during the Archaic and Formative periods. Although no other groups resided in this part of the valley when Tiwanaku settlers arrived, the region fostered culture contact among longstanding intersecting political and economic interests.

\section{Mortuary Diversity at the Omo M10 Site}

The site of Omo M10 in the middle Moquegua valley features a large residential area and a monumental ceremonial complex, as well as 14 cemetery sectors, 12 of which date to the Middle Horizon period (Figure 2). Over 200 burials $^{2}$ excavated in 11 of the Middle Horizon cemeteries of the site adhere to the Tiwanaku burial style (Baitzel 2016; Baitzel and Goldstein 2014; Blom 1999; Buikstra 1995; Goldstein 1989, 2005). Because Tiwanaku mortuary practices have been studied intensively throughout the southern Andes (see Anderson 2013; Baitzel 2016; Baitzel and Goldstein 2011, 2014; Bermann 1994; Blom 1999; Buikstra 1995; Couture and Sampeck 2003; Goldstein 1989, 1996, 2005, 2013; Hoshower et al. 1995; Korpisaari 2006; Owen 1997; Plunger 2009; Rivera 1985; Sharratt 2011; Torres-Rouff 2008; Vargas 1988), I provide only a brief overview of Tiwanaku-style burials at Omo M10 and focus in more detail on the new findings from Cemetery M10X and Cemetery M10I.

Analyses and curation of excavated materials were conducted at the Museo Contisuyo with support of museum staff. Age-at-death and sex 


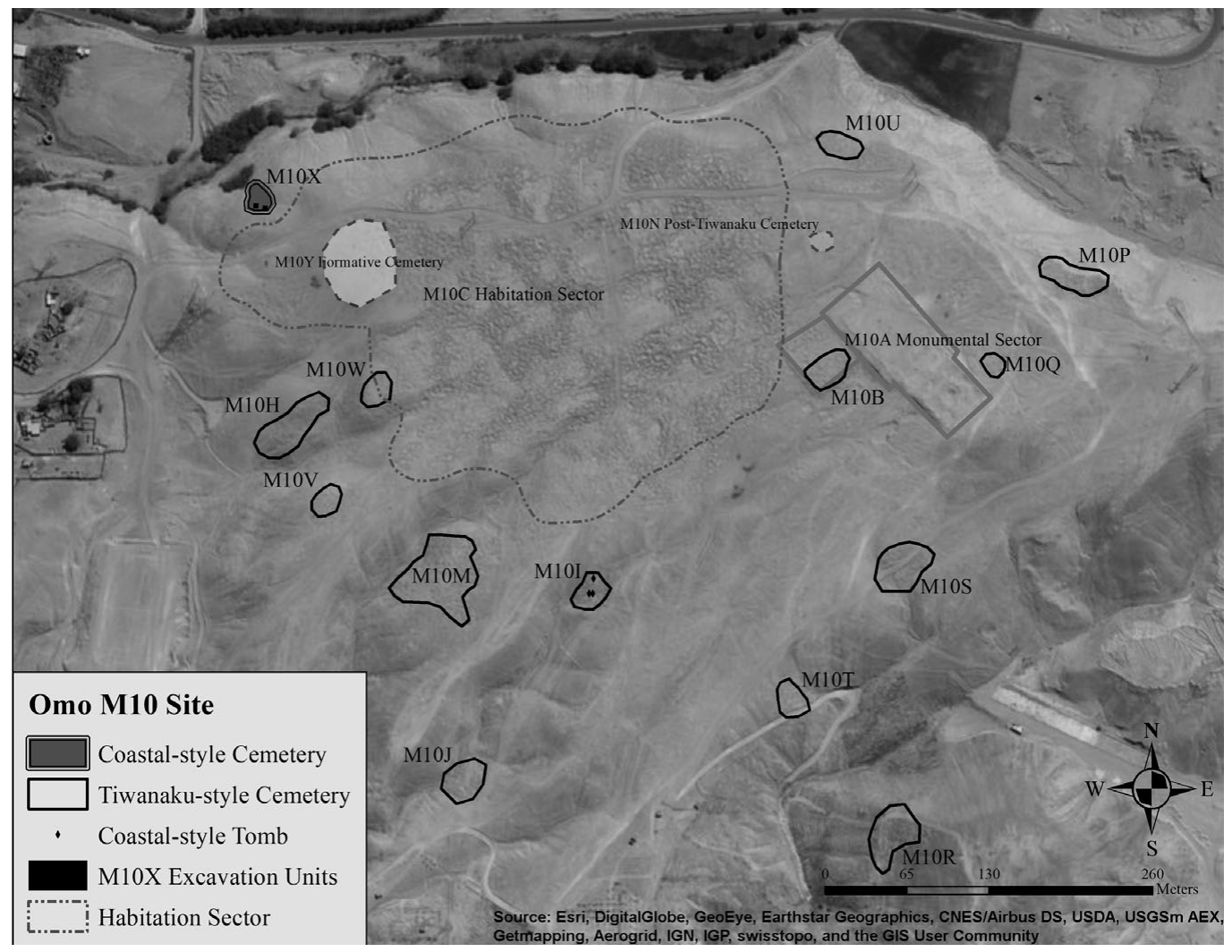

Figure 2. Planview of Omo M10 site: Tiwanaku-style cemeteries, non-Tiwanaku cemeteries. (Map by S. Baitzel using GoogleEarth source data).

were determined using standard methods for the os coxae in adults (Lovejoy et al. 1985), and dental development and epiphyseal fusions in juveniles (Buikstra and Ubelaker 1994). Cranial vault modification was assessed using criteria defined by Buikstra and Ubelaker (1994). Previous studies by Cassman (1997) and Minkes (2005) of funerary textiles in the Moquegua region were used as guidelines for the analysis of the Omo M10 textile assemblage. The ceramic materials from the Omo M10 cemeteries were analyzed using the formal-functional typology developed by Goldstein (1985) for Tiwanaku sites in the Moquegua valley.

\section{Tiwanaku-Style Burials at Omo M10}

Ninety-eight percent of the 184 Tiwanaku-style burials excavated at Omo M10 were singleindividual interments, except for two double burials (Baitzel 2016). Although group affiliation and age were the most salient factors in mourn- ers' choices regarding tomb size and style (pits, partially and fully stone-lined cists), tomb density (average 0.4 tombs $/ \mathrm{m}^{2}$ ) and depth (average $80 \mathrm{~cm}$ ) were consistent across cemeteries (Supplemental Table 1). Normative Tiwanaku burials at Omo M10 contained individuals in tightly flexed, seated position, facing east, northeast, or southeast. Social deviance in colonial Tiwanaku society was marked by interment in flexedfacedown body position, a practice reminiscent of the Tiwanaku capital (Couture and Sampeck 2003:252).

Camelid-fiber textiles-tunics and mantles woven in warp-face plainweave with simple selvedges and occasional decorative embroideries-and plant-fiber rope were used for wrapping the dead in Tiwanaku society. Approximately $50 \%$ of burials at Omo M10 contained grave offerings of serving and cooking utensils made from ceramic, wood, baskets, and gourds. On occasion, personal ornaments, such 
as greenstone bead necklaces and leather sandals, weaving tools (wooden spindles, combs, and needles), and ritual paraphernalia (bone tubes, pigment boxes, pan flutes) were included, depending on the age and sex of the deceased. Only three Tiwanaku-style burials at Omo M10 contained metal jewelry. The scarcity of metals may be the result of looting of Middle Horizon burials by later populations (Goldstein 2005:248), but the exceedingly small number of metal offerings rather suggests that these objects were either not popular as grave offerings or unavailable to Tiwanaku colonists. At the highland Tiwanaku capital, gold and silver objects have been found in elite burials (Couture and Sampeck 2003).

Radiocarbon dates from plant-fiber rope from one tomb per cemetery at Omo M10 fall into two overlapping clusters. The first cluster dates from the late seventh century to the mid-tenth century $\mathrm{AD}$, the second from the late eighth century to the mid-twelfth century AD. Overall, the Tiwanaku-style cemeteries at Omo M10 date from AD 698 to AD 1128 (2-sigma; Baitzel 2016), coinciding with published dates for the Tiwanaku occupation in Moquegua (Goldstein 2005:Table 5.3, 2013: Table 2; Sharratt 2011). A "radiocarbon plateau" in the SHcal13 calibration curve from $1200 \mathrm{cal} \mathrm{BP}$ to $900 \mathrm{cal} \mathrm{BP}$ - and the lack of alluvial deposition and stratigraphy at the Omo M10 cemeteries-preclude the possibility of establishing a more precise chronological sequence.

The only three burials that diverged from known Tiwanaku mortuary practices were in Cemetery M10I on the southwestern edge of the site. Amidst the typical Tiwanaku tombs, these burials contained the remains of adolescent or young adult individuals of female (M10I-22) and indeterminate sex (M10I-10, M10I-14). The tombs were shallow $(<15 \mathrm{~cm})$, stone-rimmed pits in which the interred individuals were placed in a supine position, their legs tightly flexed to the side. Due to the shallowness of the pits, crania and ossa coxae were damaged or missing so that cranial modification could not be assessed. The individual in M10I-10 had been wrapped in textiles and a reed mat. The only preserved offerings were two baskets and a wooden spoon in burial M10I-22. Placed within the cemetery limits, the divergent burials are considered con- temporaneous with the highland-style interments at Cemetery M10I. A radiocarbon sample from the basket found in burial M10I-22 yielded a date of cal AD 773-978 $(1153 \pm 40 \mathrm{BP}, \mathrm{M} 10=8859$, AA101915). A nearby Tiwanaku-style burial (M10I-24) yielded a similar date of AD 770 980 (1160 \pm 40 BP, AA101916) The closest analogue to the divergent burials at M10I in terms of tomb structure and body position are the Formative-period coastal burials at Wawakiki and Cemetery M10X at Omo M10, located a few hundred meters north of Cemetery M10I.

\section{Cemetery M10X}

Cemetery M10X is the only non-Tiwanaku Middle Horizon cemetery at Omo M10. It is located on the northwestern edge of the Omo M10 site, roughly equidistant from the Tiwanakustyle cemeteries nearby. Cemetery M10X is separated from the Tiwanaku residential area by a Formative-period boot tomb cemetery (Figure 2). Of the 38 tombs excavated in an area of $16 \mathrm{~m}^{2}$ (density: 1.2 tombs $/ \mathrm{m}^{2}$ ), only 15 tombs were intact enough for analysis (Supplemental Table 1). The tombs were shallow round or oval pits with an average depth of $33 \mathrm{~cm}$. Tombs crosscut and overlapped one another, such as in burials M10X-20 and M10X-23 (Figure 3), indicating recurrent use of an area unrestricted by topographic or geographical boundaries. Rocks lined pit openings, and capstones consisted of river cobbles piled on top of the funerary bundle. Individuals were interred in supine-flexed position leaning against the sloping sides of the pit $(n=12)$, or tightly flexed on either side $(n=3)$, with the feet toward east, northeast, or southeast $(n=13$; Figure 4). Reed mats used to wrap funerary bundles were a common element in Cemetery M10X burials. A reed mat from Burial M10X-17 yielded a radiocarbon date of cal AD 683-965 (2-sigma; $1249 \pm 42$ BP; AA101914; reed). The Agreement Index for M10X-17 in relation to the other dates from the cemeteries at Omo M10 is $70.9 \%$ (values above $60 \%$ are considered indicative of temporal agreement).

The only intact adult burials belonged to two female individuals (older than 50 years and 2227 years), but neither was found with cranium. Identifiable juvenile remains belonged to three infants under the age of 2 years, six young 


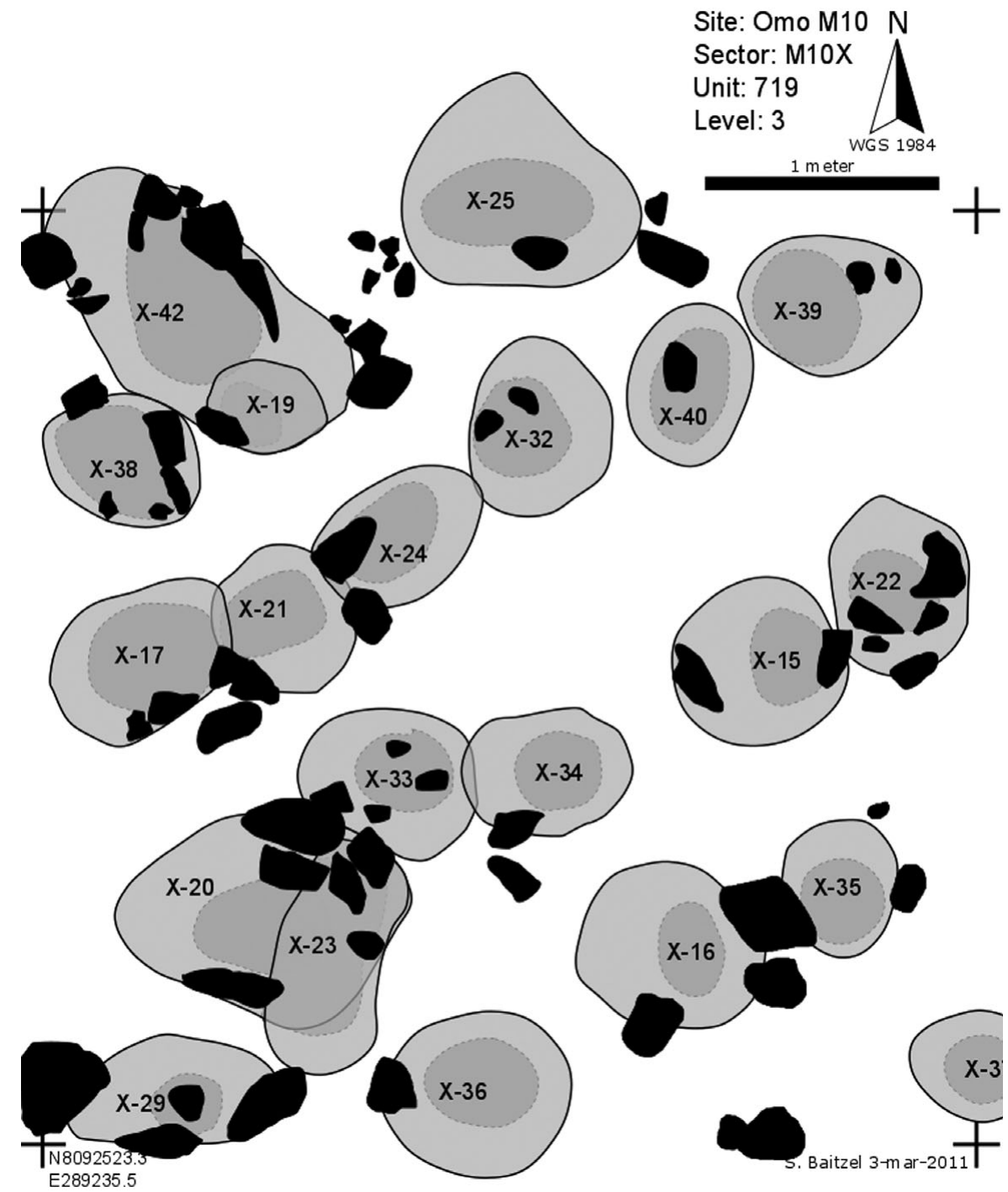

Figure 3. Planview of Unit 719 in Cemetery M10X showing superposition of burials.

children (ages 2-5 years), and four older children (ages 5-10 years). All complete crania $(\mathrm{n}=$ 11) had cranial vault modification of the frontooccipital style. This modification style is typical of the Tiwanaku highland populations in the western Andes, among the Moquegua Huaracane population, and contemporaneous coastal populations (Blom et al. 1998; Lozada and Buikstra 2005). All juvenile crania showed evidence of porotic hyperostosis and cribra orbitalia in active and advanced stages (Supplemental Table 1). Orbital roofs, occipital squamous portions and sutures were most involved. Other nonsystemic stress markers, including a bowed fibula and flaring of distal long bone epiphyses on three juvenile individuals point to prolonged systemic stress, such as would be caused by nutritional deficiencies, parasites, or other infections (Blom et al. 2005; Walker et al. 2009).

Human remains in Cemetery M10X were wrapped loosely in blankets and tunics. The textiles are warp-face structures made from brown camelid fibers. Two textiles have polychrome embroidery, also seen in Tiwanaku-style textiles in Moquegua (Baitzel 2016; Plunger 2009). Textile techniques unique to Cemetery 

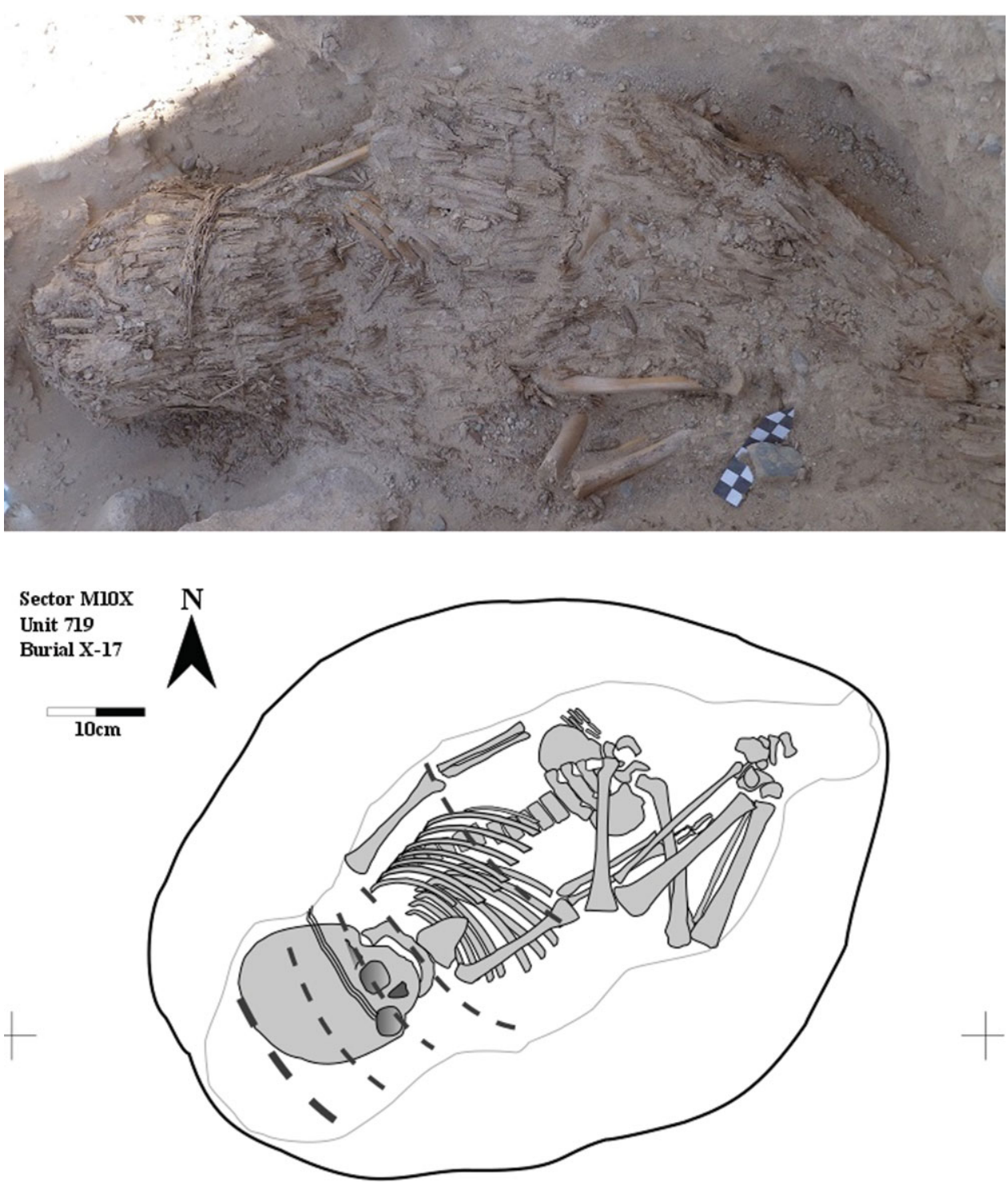

Figure 4. Planview drawing and photo of Burials X-17. ${ }^{3}$ (Drawing, photo by S. Baitzel). (Color online)

M10X included a warp-face plainweave tunic with chain-linked warp selvedge and a warpface plainweave faja (belt) buried with a juvenile (Burial M10X-32). In burial M10X-16, a narrow band of warp-face plainweave structure made from light-brown camelid fiber was found stuck horizontally to the forehead of an infant (Figure 5a); perhaps this was part of a headdress or cranial modification device, which are never found in Tiwanaku interments.

No intact ceramic vessels were found at Cemetery M10X. The 769 sherds found in dis- turbed and surface contexts present a mixture of Tiwanaku and other ceramic wares, including small percentages of Wari and Chiribaya-style wares (Supplemental Table 2; Supplemental Figure 1). Given the proximity of Cemetery M10X to the Tiwanaku residential area and associated middens, it is possible that the large numbers of Tiwanaku utilitarian plainwares $(n=505)$ and smaller numbers of decorated Tiwanaku redslipped sherds $(n=60)$ were associated with the domestic occupation of the site (Goldstein 1985). 


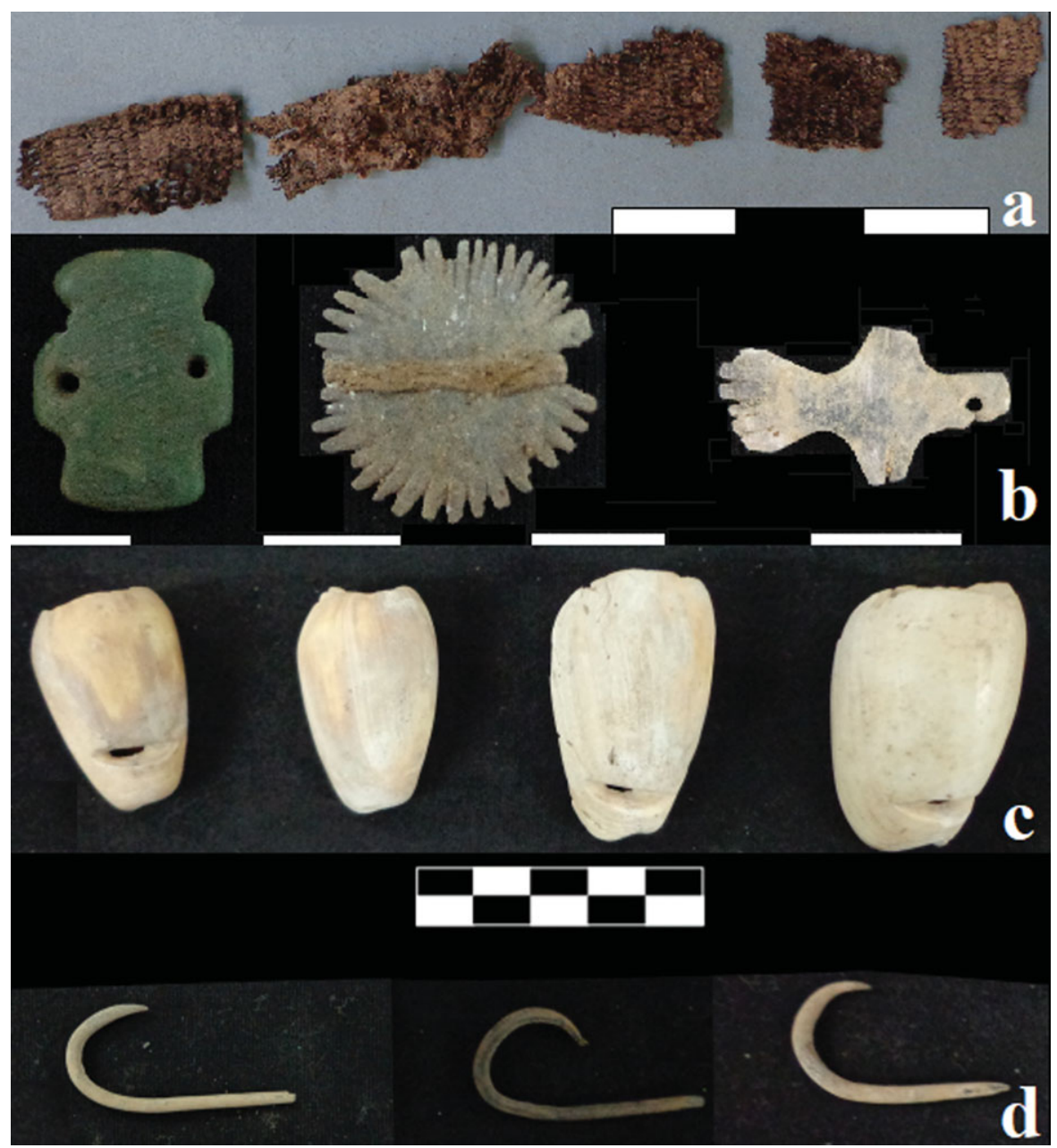

Figure 5. (a) fragments of band made from warp-face plainweave camelid-fiber structure found on frontal bone of infant in Burial M10X-16; (b) ornaments from Burials M10X-20 and M10X-23; (c) shell whistles from Burial M10X-9; (d) fishhooks from Burials M10X-30 and M10X-34. (Color online)

Nonceramic offerings were uncommon at Cemetery M10X and were found with one third of burials; this may be, in part, due to looting. A plain wooden spoon, a pin, a comb made from cactus needles, and a gourd vessel found in Cemetery M10X resemble Tiwanaku burial offerings. Similar utilitarian objects feature in south-Andean burial assemblages during earlier and later periods, as well (Uribe and Agüero 2004). Ornaments made from stone and shell were the most popular grave offering at Cemetery M10X and differ from Tiwanaku funerary goods. Stone beads were manufactured from green and white stone (Figure 5b). Shell ornaments consisted of large, notched Olivela peruvianis shells (Figure 5c), spiral and disk beads, and two pendant ornaments crafted from Choromytilus shell (Figure 5b). Only three cactus-spine fishhooks have been recovered at Omo M10 to date, all at Cemetery M10X (Figure 5d). Metal ornaments included several copper and silver rings, and small rolled-up sheets of silver. Green discoloration on the shoulder and thoracic bones of a young child in burial M10X-11 suggest that the funerary attire of this individual may have included a copper pectoral plate that oxidized and stained the bones before the removal of the object. 


\section{Discussion}

Based on the differences in mortuary practices observed at Omo M10, it is probable that Cemetery M10X occupants had cultural origins distinct from the highland colonists buried at the site (Supplemental Table 1). Tomb structure, body position and orientation, and grave offerings at Cemetery M10X resemble the Formative-period mortuary tradition of the Pacific littoral (Jessup 1991); the beads found in Cemetery M10X are similar to those recovered in indigenous middle valley (Huaracane) burials. Our limited knowledge of Formative-period mortuary variability in the region precludes any assessment of the relationship between indigenous populations and the Cemetery M10X group, but the coastal cultural identity of the latter seems plausible based on this evidence.

The unusual presence of a coastal-style cemetery in the middle Moquegua valley is further highlighted by the fact that there is no evidence of members of the M10X group residing at or near Omo M10. Neither extensive survey nor excavations identified non-Tiwanaku Middle Horizon domestic component at the site (Goldstein 1989, 2005). Similarly, research at other Tiwanaku settlements in Moquegua has not produced evidence of sustained nonhighland occupation, nor have any non-Tiwanaku culture groups been identified in the middle Moquegua valley for this time (Goldstein 2005). We therefore do not know from whence the M10X community commenced their funerary processions, or how permanent their presence in the middle valley was beyond the performance of funerary ritual. Temporary camp sites, perhaps linked to seasonal mobility, presents a possible scenario that would leave behind little archaeological evidence.

Extensive looting at Cemetery M10X precludes a detailed paleodemographic analysis, but tomb size offers an alternative way for estimating age-at-death. The normative body position in Cemetery M10X was reclined or supine with flexed lower limbs. Based on intact burials, I estimate that adults required tombs longer than $80 \mathrm{~cm}$, whereas pits shorter than $80 \mathrm{~cm}$ would accommodate subadults. Thirty-two of the 38 excavated tombs at Cemetery M10X measured fewer than $80 \mathrm{~cm}$ in length, which suggests that $84 \%$ of excavated burials had contained juvenile individuals. This percentage is unusually high even for prehistoric cemeteries. The taphonomy, sample size, and lack of more precise age-at-death estimates present limitations to interpretation, but I would tentatively argue that the Cemetery M10X population experienced high morbidity, fertility, or mortality rates, compounded by prolonged experiences of systemic stress reflected in the elevated frequencies of Porotic hyperostosis and Cribra orbitalia.

Tiwanaku cranial vault modification is considered a marker of cultural identity (Hoshower et al. 1995). The fronto-occipital cranial modification style at Cemetery M10X matches that of Tiwanaku populations. Blom and colleagues (1998) noted similarities in cranial modification styles of highland and indigenous groups in Moquegua. It is possible that in this case cultural differences were expressed through hairstyle and headdress, not just cranial shape (Agüero 1994). At Cemetery M10X, analysis could only be conducted on juvenile crania. If Cemetery M10X overlapped for some time with the highland occupation of Omo M10, similar cranial modification styles in Tiwanaku and M10X individuals could also reflect the assimilative practices of coastal immigrants who sought to establish social affiliation with provincial Tiwanaku society by modifying the crania of their descendants.

Contemporaneity of the Cemetery M10X and the Tiwanaku occupation of Omo M10 is central to inferring culture contact between highland and coastal groups. The Omo M10 cemeteries are spatially discrete; this, together with the lack of alluvial deposits, makes it difficult to establish a relative chronology. The radiocarbon date from M10X-17 coincides with the Tiwanakuaffiliated occupation of Omo M10, suggesting that Cemetery M10X was in use during the first half of the Moquegua Middle Horizon. ${ }^{4}$ Given that the cemetery area is unconfined by any natural boundaries, the crowding of tombs in M10X could indicate prolonged use or a cultural practice distinct from the spaced-out Tiwanaku burials. At least $15 \%$ of M10X burials cut into other, unmarked tombs. Formative tumuli and boot tombs. in comparison, were used repeatedly (Goldstein 2000:349). If the prolonged use of mortuary space exceeded individual mourners' 
memories, mourners may have cut unwittingly into earlier burial contexts. The estimated population size of the cemetery and the presence of juveniles and adults in Cemetery M10X also point to prolonged, multigenerational cemetery use, barring the unlikely occurrence of a catastrophic event that decimated the M10X population. Radiocarbon dates allow us to establish contemporaneity of Tiwanaku and coastal culture groups at Omo M10, and several other indicators point to the prolonged use of the M10X cemetery.

Assuming M10X was used for longer than a generation, its founding may either predate the Tiwanaku colonization and the cemetery was in use as Tiwanaku settlers arrived, or the founding of the M10X cemetery coincides with the arrival of the Tiwanaku settlers. In the case of the first scenario, I would speculate that the location of Cemetery M10X near an abandoned Formativeperiod cemetery (M10Y) may have signaled affinity, shared histories, or exchange relationships with indigenous middle valley inhabitants. Furthermore, the Formative boot-tomb cemetery separates the different communities of the dead at Omo M10, and may have served as a buffer to the highlanders who encountered an actively used coastal cemetery. Nevertheless, because coastal groups did not permanently reside in the middle valley, the highland colonists who arrived in large numbers may not have shied away from building a settlement so near these foreign and abandoned cemeteries.

Alternately, I would argue that the radiocarbon date may reflect the founding of the cemetery, so that its formation would have coincided with the arrival of Tiwanaku highlanders in the region in the seventh century AD. This coastal group may have perceived the arrival of highlanders to this abandoned area of the valley as a welcome opportunity to re-establish vertical exchange patterns that had fallen victim to the departure of the middle valley Huaracane population. The coastal community might have specifically targeted Omo M10, the administrative center of the Tiwanaku presence in the valley. The above present possible scenarios for explaining the isolated presence of a coastal-style cemetery at Omo M10. Without a better grasp of the occupational history of the cemetery, and given the lack of coastal sites nearby, I refrain from further speculations about the effects that contact may have had on coastal communities. Unfortunately, the small number of undisturbed datable contexts at Omo M10X, and the limitations of the radiocarbon curve plateau, pose a serious challenge to studying contact and change from the perspective of the Cemetery M10X community.

I will instead consider the effects contact had on the Tiwanaku occupants of Omo M10 for whom more evidence is available. As late as the twelfth century $\mathrm{AD}$, mortuary practices at the site remained highly conservative (Baitzel 2016). The only evidence for foreign influence were three coastal-style burials in a Tiwanaku-style cemetery. One of these burials dates to the tenth century AD. Beyond these burials, evidence that Tiwanaku residents of Omo M10 made contact with other culture groups in the area is rare. For Tiwanaku settlers in Moquegua, exchange and mobility networks were oriented toward their homeland. Marine foods were not attractive for highlanders who relied on a diet of maize and camelid meat, as indicated by the minute percentage of marine shell in early Tiwanaku middens in Moquegua, and by dietary stable isotope ratios in human remains (Goldstein 2003; Sandness 1992; Somerville et al. 2015). Shells and especially metals, which, judging from their frequent inclusion in M10X burials, were accessible to coastal communities, would have incentivized Tiwanaku colonists to seek exchange with coastal groups. These products might have been traded for highland resources such as camelid wool and dyes, as well as items from the eastern Andes (e.g., coca) where Tiwanaku had colonies. For millennia, populations along the south coast of the Andes relied on trade to access longdistance staple and prestige items (Nuñez and Dillehay 1995). Scarcity of coastal resources in the early Tiwanaku occupations at Omo M10 suggests that the scale and impact of exchange with coastal groups was initially small and may not have been sustained during the early phases of settlement.

Tiwanaku contact with the coastal M10X community was limited to ritual contexts, in this case funerary rituals that were performed in close proximity of the other culture group. This fits with observations made in other areas 
of the valley about Tiwanaku extra-community interactions. Evidence for Tiwanaku's contact with the Wari polity, a powerful state that exerted its influence over the upper Moquegua valley, has been found exclusively in mortuary and other ceremonial contexts (Garcia Marquez 1990; Williams 2013:37). This would suggest that, although not entirely isolationist in their foreign policy, Tiwanaku settlers in Moquegua limited interactions with other cultures to formalized ritual performances aimed at displaying and performing their beliefs and highland customs. The centrality of mortuary rituals in culturecontact situations also highlights their importance for affirming cultural identities away from home. Colonial Tiwanaku and coastal cemeteries established local roots for settler colonists and sojourners.

Two centuries after colonization, Tiwanaku colonizers increased their use of marine shells for bead production and food consumption at Omo M10 suggesting the relationship with coastal groups intensified during later times (Goldstein 1989:240). Three coastal-style burials of young adults found in Cemetery M10I date to the later Middle Horizon. They may represent the gradual integration of coastal individuals into the Tiwanaku settler community during a time when marine resources gained popularity among the descendants of highland immigrants. Because they were buried according to the traditions of their coastal origin, it is possible that these young adults retained a connection to their home community at the time of their death. Their inclusion into the M10I mortuary community, however, signals that they were considered members of colonial society. While this does not constitute direct evidence of hybridity or acculturation, it raises the possibility that initial culture contact, although fleeting and insubstantial, was revived after several generations and took on different, more profound form. Future bioarchaeological studies of genetic, dietary, and mobility patterns will elucidate how individuals facilitated and embodied contact between these two groups.

\section{Conclusion}

Based on contemporaneity and spatial proximity, contact very likely occurred between high- land and coastal groups around the seventh century AD. It did not substantially change coastal mortuary traditions as represented at Omo M10, or the cultural practices (mortuary and nonmortuary) of highland colonists in the middle Moquegua valley for some generations. Although it is difficult to ascertain the duration of contact between coastal visitors and highland settlers from the evidence, culturally diverse cemeteries at Omo M10 offer important insights into the dynamics that form culture contact without culture change.

Regional culture histories are an important vantage point for constructing motives and modes of contact in the absence of concrete material evidence to elucidate the nature of interaction. Economic interests and longstanding exchange structures may have caused coastal groups to approach highlanders in the middle valley, but there is no evidence to suggest that the demographically dominant party in this encounter, the Tiwanaku highlanders, were interested in sustained interaction in the seventh century AD. Nevertheless, both groups founded and maintained cemeteries near the highland town, so that the periodic performance of funerary rituals would have expressed cultural difference and mutual recognition of another mortuary landscape. Rather than representing conflict or competition over resources, the coexistence of diverse ancestral communities at Omo M10 reflects an unthreatening and uninvolved attitude on the part of both culture groups. During subsequent phases of occupation, the interests of Tiwanaku colonists, after residing for some time in the region, may have changed, resulting in trade with coastal region. Culture contact does not always result in culture change. The circumstances that prevent change, although difficult to detect materially, nevertheless elucidate why and how contact remained without lasting impact. We must carefully assess local histories to capture cultural encounters that have seemingly little impact on the trajectories of the different culture groups involved, and that nevertheless convey information about the attitudes, beliefs, and circumstances that shape culture contact.

Acknowledgments. I thank Dr. Paul Goldstein and Lic. Patricia Palacios, directors of the Proyecto Arqueológico 
Omo 2010-2012. This research was conducted with support of Fulbright-Hays, National Science Foundation grant BCS1240007, the University of California San Diego Department of Anthropology, and the Dumbarton Oaks Research Library. I also thank the Museo Contisuyo and the Ministerio de Cultura Moquegua for their logistical support, and all the individuals, in particular Ben Volta, who participated in the excavation and analysis of the materials presented here. This research was conducted with permission from the Ministerio de Cultura Peru Resolución Direccional Nacional $\mathrm{N}^{\circ} 1618 / \mathrm{INC}$ in 2010-2012.

Data Availability Statement. Excavated materials presented in this paper are housed in the Museo Contisuyo in Moquegua, Peru, and are available for study with the permission of the Peruvian Ministerio de Cultura. Digital data analysis results are stored at the Southamerican Archaeology Laboratory at Washington University in St. Louis and are available upon request.

Supplemental Material. For supplementary material accompanying this article, visit https://doi.org/10.1017/laq.2018.25 M10X.

Supplemental Figure 1. Ceramic sherds from Cemetery

Supplemental Table 1. Mortuary Attributes of Middle Horizon and Formative Cemeteries in Moquegua.

Supplemental Table 2. Frequency of ceramic fragments from Cemetery M10X.

\section{References Cited}

Agüero, Carolina

1994 Clasificación de los Turbantes del Período Formativo Temprano en el Norte de Chile. Boletín del Comité Nacional de Conservación Textil 2:61-70.

Agüero, Carolina, and Mauricio Uribe, R.

2015 Tombs and Tumuli on the Coast and Pampa of Tarapacá: Explaining the Formative Period in Northern Chile (South-Central Andes). In Funerary Practices and Models in the Ancient Andes, edited by Peter Eeckhout, and Lawrence S. Owens, pp. 55-68. Cambridge University Press, Cambridge.

Alcock, Susan E.

2005 Roman Colonies in the Eastern Empire: A Tale of Four Cities. In The Archaeology of Colonial Encounters: Comparative Perspectives, edited by Gil J. Stein, pp. 297-330. School of American Research Press, Santa Fe.

Aldenderfer, Mark S.

1990 El Periodo Arcaico en la Cuenca del Osmore. In Trabajos Arqueológicos en Moquegua, Peru, Vol.1, edited by Luis K. Watanabe, Michael E. Moseley, and Fernando Cabieses, pp. 37-62. Programa Contisuyo del Museo Peruano de Ciencias de la Salud, Moquegua, Peru.

Anderson, Karen

2013 Tiwanaku Influence on the Central Valley of Cochabamba. In Visions of Tiwanaku, edited by Alexei Vranich and Charles Stanish, pp. 87-112. Monograph 78. Cotsen Institute of Archaeology, Los Angeles. Baitzel, Sarah I.

2016 The Politics of Death and Identity in Provincial Tiwanaku Society (A.D. 600-1100). Unpublished PhD dissertation, Department of Anthropology, UC San Diego, La Jolla.

Baitzel, Sarah I., and Paul S. Goldstein

2011 Manifesting Ethnic Identity in an Ancient Society: Evidence from a Tiwanaku Cemetery in Moquegua, Peru. In Ethnicity from Various Angles and Through Varied Lenses: Yesterday's Today in Latin America, edited by Christine Hunefeldt and Leon Zamosc, pp. 30-44. Sussex Academic Press, Portland, Oregon.

2014 More Than The Sum of Its Parts: Dress and Social Identity in a Provincial Tiwanaku Child Burial. Journal of Anthropological Archaeology 35:51-62.

Barker, Graeme

2000 Farmers, Herders and Miners in the Wadi Faynan, Southern Jordan: A 10,000-Year Landscape Archaeology. In The Archaeology of Drylands: Living at the Margin, edited by Graeme Barker and David Gilbertson, pp. 63-85. Routledge, New York.

Bawden, Garth

1990 Ecología cultural pre Inca de la región de Ilo. In Trabajos arqueológicos en Moquegua, Peru, Vol. 1, edited by Luis K. Watanabe, Michael E. Moseley, and Fernando Cabieses, pp. 185-214. Programa Contisuyo del Museo Peruano de Ciencias de la Salud, Moquegua, Peru.

Beck, Lane A. (editor)

1995 Regional Appraoches to Mortuary Analysis. Plenum Press, New York.

Bermann, Marc

1994 Lukurmata: Household Archaeology in Prehispanic Bolivia. Princeton University Press, Princeton, New Jersey.

Blom, Deborah E.

1999 Tiwanaku Regional Interaction and Social Identity: A Bioarchaeological Approach. Unpublished PhD dissertation, Department of Anthropology, University of Chicago.

Blom, Deborah E., Jane E. Buikstra, Linda Keng, Paula D. Tomczak, Eleanor Shoreman, and Debbie StevensTuttle

2005 Anemia and Childhood Mortality: Latitudinal Patterning Along the Coast of Pre-Columbian Peru. American Journal of Physical Anthropology 127:152-169.

Blom, Deborah E., Benedikt Hallgrimsson, Linda Keng, María C. Lozada, and Jane E. Buikstra

1998 Tiwanaku "Colonization": Bioarchaeological Implications for Migration in the Moquegua Valley. World Archaeology 30(2):238-261.

Buikstra, Jane E.

1995 Tombs for the Living...or...for the Dead: The Osmore Ancestors. In Tombs for the Living: Andean Mortuary Practices. A Symposium at Dumbarton Oaks, 12th and 13th October 1991, edited by Tom D. Dillehay, pp. 229 280. Dumbarton Oaks Research Library and Collection, Washington, DC.

2005 Discussion: Ethnogenesis and Ethnicity in the Andes. In Us and Them: Archaeology and Ethnicity in the Andes, edited by Richard M. Reycraft, pp. 233-238. Monograph 53. Cotsen Institute of Archaeology, Los Angeles.

Buikstra, Jane E., and Douglas H. Ubelaker

1994 Standards for Data Collection from Human Skeletal Remains: Proceedings of a Seminar at the Field Museum of Natural History. Arkansas Archaeological Report Research Series 45. Arkansas Archaeology Survey, Fayetteville. 
Buzon, Michele R.

2006 Biological and Ethnic Identity in New Kingdom Nubia. Current Anthropology 47(4):683-695.

Carr, Christopher

1995 Mortuary Practices: Their Social, PhilosophicalReligious, Circumstantial, and Physical Determinants. Journal of Archaeological Method and Theory 2(2):105-200.

Cassman, Vicki

1997 A Reconsideration of Prehistoric Ethnicity and Status in Northern Chile: The Textile Evidence. Unpublished PhD dissertation, Department of Anthropology, Arizona State University, Tempe.

Castillo, Butters, Luis Jaime, Francesca Fernandini, and Luis Muro

2012 The Multidimensional Relations Between the Wari and the Moche States of Northern Peru. Boletin de Arqueologia PUCP 16:53-77.

Chapman, Robert, Ian Kinnes, and Klaus Randsborg (editors) 1981 The Archaeology of Death. New Directions in Archaeology. Cambridge University Press, Cambridge. Cool, Hillary E.M.

2010 Finding the Foreigners. Journal of Roman Archaeology 78:27-44.

Costion, Kirk E

2013 Formative Period and Middle Horizon Occupations at the Huaracane Settlement of Yahuay Alta in the Middle Moquegua Valley, Peru. Chungará 45(4):561579.

Couture, Nicole C., and Kathryn Sampeck

2003 Putuni: A History of Palace Architecture at Tiwanaku. In Tiwanaku and Its Hinterland: Archaeology and Palaeoecology of an Andean Civilization, edited by Alan L. Kolata, pp. 226-265. Urban and Rural Archaeology 2. Smithsonian Institution Press, Washington, DC.

D'Altroy, Terrence

2002 The Incas. Blackwell, Malden, Massachusetts.

Dillehay, Tom D. (editor)

1995 Tombs for the Living: Andean Mortuary Practices: A Symposium at Dumbarton Oaks 12th and 13th October 1991. Dumbarton Oaks Research Library and Collection, Washington, DC.

Emerson, Thomas E., and Eve Hargrave

2000 Strangers in Paradise? Recognizing Ethnic Mortuary Diversity on the Fringes of Cahokia. Southeastern Archaeology 19(1):1-23.

Feldman, Robert A

1990 La cerámica del período temprano en Moquegua. In Trabajos Arqueológicos en Moquegua, Vol. 1, edited by Luis K. Watanabe, Michel Edward Moseley, and Fernando Cabieses, pp. 227-236. Programa Contisuyo del Museo Peruano de Ciencias de la Salud, Moquegua, Peru.

Frye, Kyle, and Edmundo de la Vega

2005 The Altiplano Period in the Titicaca Basin. In Advances in Titicaca Basin Archaeology - 1, edited by Charles Stanish, Amanda Cohen, and Mark S. Aldenderfer, pp. 173-184. Cotsen Institute of Archaeology, Los Angeles.

Garcia Marquez, Manuel

1990 Excavación en el cementerio de Chen Chen, Moquegua, una interacción de contextos funerarios Tiwanaku/Wari. Unpublished dissertation, Universidad Católica de Santa Maria, Arequipa, Peru.

Goldstein, Lynne

1981 One-Dimensional Archaeology and MultiDimensional People: Spatial Organisation and Mortuary
Analysis. In The Archaeology of Death, edited by Robert Chapman, Ian Kinnes, and Klavs Randsborg, pp. 53-69. Cambridge University Press, Cambridge.

Goldstein, Paul S.

1985 Tiwanaku Ceramics of the Moquegua Valley, Peru. Unpublished Master's thesis, Department of Anthropology, University of Chicago.

1989 Omo, a Tiwanaku Provincial Center in Moquegua, Peru. Unpublished PhD dissertation, Department of Anthropology, University of Chicago, Chicago.

1996 Tiwanaku Settlement Patterns of the Azapa Valley, Chile: New Data and the Legacy of Percy Dauelsberg. Diálogo Andino 14(15):57-74.

2000 Exotic Goods and Everyday Chiefs: Long-Distance Exchange and Indigenous Sociopolitical Development in the South Central Andes. Latin American Antiquity 11(4):335-361.

2003 From Stew-Eaters to Maize-Drinkers. In The Archaeology and Politics of Food and Feasting in Early States and Empires, edited by Tamara L. Bray, pp. 143-172. Kluwer Academic/Plenum Press, New York.

2005 Andean Diaspora: The Tiwanaku Colonies and the Origins of South American Empire. University Press of Florida, Gainesville.

2009 Diasporas within the Ancient State: Tiwanaku as Ayllus in Motion. In Andean Civilization: A Tribute to Michael E. Moseley, edited by Joyce Marcus and Patrick R. Williams, pp. 277-302. Monograph 63. Cotsen Institute of Archaeology, Los Angeles.

2013 Tiwanaku and Wari State Expansion: Demographic and Outpost Colonization Compared. In Visions of Tiwanaku, edited by Alexei Vranich and Charles Stanish, pp. 41-63. Monograph 78. Cotsen Institute of Archaeology, Los Angeles.

2015 Multiethnicity, Pluralism, and Migration in the South Central Andes: An Alternate Path to State Expansion. Proceedings of the National Academy of Sciences 112(30):9202-9209.

Gosden, Chris

2004 Archaeology and Colonialism: Cultural Contact from $5000 \mathrm{BC}$ to the Present. Cambridge University Press, New York.

Hoshower, Lisa M., Jane E. Buikstra, Paul S. Goldstein, and Ann D. Webster

1995 Artificial Cranial Deformation at the Omo M10 Site: A Tiwanaku Complex from the Moquegua Valley, Peru. Latin American Antiquity 6:145-164.

Jessup, David

1991 General Trends in the Development of the Chiribaya Culture, South-Coastal Peru. Paper presented at the 56th Annual Meetings of the Society for American Archaeology. New Orleans.

Korpisaari, Antti

2006 Death in the Bolivian High Plateau: Burials and Tiwanaku Society. British Archaeological Reports International Series (1536), Oxford.

Lau, George F.

2002 Feasting and Ancestor Veneration at Chinchawas, North Highlands of Ancash, Peru. Latin American Antiquity 13:279-304.

Lightfoot, Kent G.

1995 Culture Contact Studies: Redefining the Relationship between Prehistoric and Historical Archaeology. American Antiquity 60:199-217.

Lightfoot, Kent G., and Antoinette Martinez

1995 Frontiers and Boundaries in Archaeological Perspective. Annual Review of Anthropology 24:471-492. 
Lovejoy, C. Owen, Richard S. Meindl, Thomas R. Pryzbeck, and Robert P. Mensforth

1985 Chronological Metamorphosis of the Auricular Surface of the Ilium: A New Method for the Determination of Adult Skeletal Age at Death. American Journal of Physical Anthropology 68(1):15-28.

Lozada, María Cecilia, and Jane E Buikstra

2002 El señorío de Chiribaya en la costa sur del Perú. Instituto de Estudios Peruanos, Lima, Peru.

2005 Pescadores and Labradores Among the Señorio de Chiribaya in Southern Peru. In Us and Them: Archaeology and Ethnicity in the Andes, edited by Richard Martin Reycraft, pp. 206-225. Monograph 53. Cotsen Institute of Archaeology, Los Angeles.

Lyons, Claire L., and John K. Papadopoulous (editors).

2002 The Archaeology of Colonialism. Getty Research Institute, Los Angeles.

Magilligan, Francis J., and Paul S. Goldstein

2001 El Niño Floods and Culture Change: A late Holocene Flood History for the Rio Moquegua, Southern Peru. Geology 29(5):431-434.

Mantha, Alexis

2009 Territoriality, Social Boundaries and Ancestor Veneration in the Central Andes of Peru. Journal of Anthropological Archaeology 28(2):158-176.

Minkes, Willi

2005 Wrap the Dead: The Funeral Textile Tradition from the Osmore Valley, South Peru and its Socio-Political Implications. Unpublished PhD dissertation, Faculty of Archaeology, Leiden University, Leiden, Netherlands.

Mullins, Paul R., and Robert Paynter

2000 Representing Colonizers: An Archaeology of Creolization, Ethnogenesis, and Indigenous Material Culture among the Haida. Historical Archaeology 34(3):73-84.

Murra, John V.

1972 El "control vertical" de un máximo de pisos ecológicos en la economáa de las sociedades andina. In Visita de la provincia de Leon de Huanuco en 1562, edited by John V. Murra, pp. 427-476. Universidad Nacional Hermilio Valdizan, Huanuco, Peru.

Murray, Tim

2004 The Archaeology of Contact in Settler Societies. Cambridge University Press, New York.

Nuñez, Lautaro, and Tom D. Dillehay

1995 Movilidad giratoria, armonía social y desarrollo en los Andes Meridionales: Patrones de tráfico $e$ interacción económica. Universidad Católica del Norte, Antofagasta, Chile.

Owen, Bruce D.

1997 Informe de Excavaciones en los Sectores Mortuorios de Chen Chen. Unpublished Final report. Instituto Nacional de Cultura, Moquegua, Peru.

2005 Distant Colonies and Explosive Collapse: The Two Stages of the Tiwanaku Diaspora in the Osmore Drainage. Latin American Antiquity 16:45-80.

Parker, Bradley J., and Lars Rodseth (editors)

2005 Untaming the Frontier in Anthropology, Archaeology, and History. University of Arizona Press, Tucson.

Peebles, Christopher S., and Susan M. Kus

1977 Some Archaeological Correlates of Ranked Society. American Antiquity 42:421-448.

Plunger, Elizabeth M.

2009 Woven Connections: Group Identity, Style, and the Textiles of the "A" and" B" Cemeteries at the Site of Río Muerto (M43), Moquegua Valley, Southern Peru. Unpublished Master's thesis, Department of Anthropology, University of California, San Diego.
Rice, Prudence

2013 Space-Time Perspectives on Colonial Moquegua. University Press of Colorado, Boulder.

Rivera, Mario A.

1985 Alto Ramírez y Tiwanaku: Un case de interpretación simbólica a través de datos arqueológicos en el área de los valles occidentales, sur del Perú y norte de Chile. Diálogo Andino 4:39-58.

Rockman, Marcy, and James Steele (editors).

2003 Colonization of Unfamiliar Landscapes: The Archaeology of Adaptation. Routledge, New York.

Romero Guevara, Álvaro Luis, Calogero M. Santoro, Daniela Valenzuela R., Juan Chacama R., Eugenia Rosello N., and Luigi Piacenza

2004 Túmulos, Ideología y Paisaje de la Fase Alto Ramírez del Valle de Azapa. Chungará 36(sp.supp.1): 261-272.

Rosen, Steven A.

2000 The Decline of Desert Agriculture: A View from the Classical Period Negev. In The Archaeology of Drylands: Living at the Margin, edited by Graeme Barker and David Gilbertson, pp. 45-62. Routledge, New York.

Rostworowski de Diez Canseco, María

1975 Pescadores, artesanos y mercadores costeños en el Perú prehispánico. Revista del Museo Nacional Lima 41:311-349.

Salazar, Lucy C.

2007 Machu Picchu's Silent Majority: A Consideration of the Inka Cemeteries. In Variations in the Expression of Inka Power: A Symposium at Dumbarton Oaks 18 and 19 October 1997, edited by Richard L. Burger, Craig Morris, and Ramiro, Matos M., pp. 165-184. Dumbarton Oaks Research Library and Collection, Washington, DC.

Sandness, Karen

1992 Temporal and Spatial Dietary Variability in the Prehistoric Lower and Middle Osmore Drainage: The Carbon and Nitrogen Isotope Evidence. Unpublished Master's thesis, Department of Anthropology, University of Nebraska, Omaha.

Sharratt, Nicola

2011 Social Identities and State Collapse: A Diachronic study of Tiwanaku Burials in the Moquegua Valley, Peru. Unpublished PhD dissertation, Department of Anthropology, University of Illinois Chicago.

2017 Steering Clear of the Dead: Avoiding Ancestors in the Moquegua Valley, Peru. American Anthropologist 119(4):645-661.

Shimada, Izumi, and James L. Fitzsimmons

2015 Living with the Dead in the Andes. University of Arizona Press, Tucson.

Silliman, Stephen W.

2005 Culture Contact or Colonialism? Challenges in the Archaeology of Native North America. American Antiquity 70:55-74.

Somerville, Andrew D., Paul S. Goldstein, Sarah I. Baitzel, Karin L. Bruwelheide, Allisen C. Dahlstedt, Linda Yzurdiaga, Sarah Raubenheimer, Kelly J. Knudson, and Margaret J. Schoeninger

2015 Diet and Gender in the Tiwanaku Colonies: Stable Isotope Analysis of Human Bone Collagen and Apatite from Moquegua, Peru. American Journal of Physical Anthropology 158(3):408-422.

Spence, Michael W.

2005 AZapotec Diaspora Network in Classic-Period Central Mexico. In The Archaeology of Colonial Encounters: Comparative Perspectives, edited by Gil J. Stein, 
pp. 173-206. School of American Research Press, Santa $\mathrm{Fe}$.

Stein, Gil J.

2002 From Passive Periphery to Active Agents: Emerging Perspectives in the Archaeology of Interregional Interaction. American Anthropologist 104(3):903-916.

2005 Introduction: The Comparative Archaeology of Colonial Encounters. In The Archaeology of Colonial Encounters: Comparative Perspectives, edited by Gil J. Stein, pp. 3-32. School of American Research Press, Santa Fe.

Stockhammer, Philipp W.

2012 Conceptualizing Cultural Hybridization in Archaeology. In Conceptualizing Cultural Hybridization: A Transdisciplinary Approach, edited by Philipp Wolfgang Stockhammer, pp. 43-58. Springer, Heidelberg.

Stovel, Emily

2001 Patrones funerarios de San Pedro de Atacama y el problema de la presencia de los contextos tiwanaku. Boletín de Arqueología PUCP 5:375-395.

2013 Concepts of Ethnicity and Culture in Andean Archaeology. Latin American Antiquity 24:3-20.

Torres-Rouff, Christina

2008 The Influence of Tiwanaku on Life in the Chilean Atacama: Mortuary and Bodily Perspectives. American Anthropologist 110(3):325-337.

Turner, Bethany L., George D. Kamenov, John D. Kingston, and George J. Armelagos

2009 Insights into Immigration and Social Class at Machu Picchu, Peru Based on Oxygen, Strontium, and Lead Isotopic Analysis. Journal of Archaeological Science 36(2):317-332.

Uribe, Mauricio, and Carolina Agüero

2004 Iconografía, alfarería y textilería Tiwanaku: elementos para una revisión del Período Medio en el Norte Grande de Chile. Chungará (Arica) 36:1055-1068.

Vargas V., Berta

1988 Informe final del proyecto "Rescate arqueológico del cementerio de Chen Chen." Unpublished final report. Instituto Nacional de Cultura, Moquegua, Peru.

van Dommelen, Peter

2005 Colonial Interactions and Hybrid Places: Phoenician and Carthaginian Settlement in the Ancient Mediterranean. In The Archaeology of Colonial Encounters: Comparative Perspectives, edited by Gil J. Stein, pp. 109-142. School of American Research Press, Santa Fe.

Voss, Barbara L.

2008 The Archaeology of Ethnogenesis: Race and Sexuality in Colonial San Francisco. University of California Press, Berkeley.

Walker, Phillip L., Rhonda R. Bathurst, Rebecca Richman, Thor Gjerdrum, and Valerie A. Andrushko

2009 The Causes of Porotic Hyperostosis and Cribra Orbitalia: A Reappraisal of the Iron-Deficiency-Anemia Hypothesis. American Journal of Physical Anthropology 139(2):109-125.

Williams, Patrick R.

1997 The Role of Disaster in the Development of Agriculture and the Evolution of Social Complexity in the
South-Central Andes. Unpublished PhD dissertation, Department of Anthropology, University of Florida, Gainesville.

2013 Tiwanaku: A Cult of the Masses. In Visions of Tiwanaku, edited by Vranich Alexei, and Charles Stanish, pp. 27-40. Cotsen Institute of Archaeology, Los Angeles.

\section{Notes}

1. The recalibration of an original radiocarbon date of $2140 \pm 240$ years BP yields a date of $776 \mathrm{BC}$ to AD 379 (2-sigma), contemporaneous with the mid-valley Huaracane occupation.

2. Sixty-nine burials were excavated in $1984 / 7$ under Programa Contisuyo. An additional 184 burials were excavated by the author as part of the Proyecto Arqueológico Omo 2010-2011.

3. Note from the Co-Editors. Prior to publication, figures in this manuscript were carefully reviewed by the SAA President. This was necessary because of the principles and practices of the SAA, as summarized in the style guide for all three journals:

Out of respect for diverse cultural traditions, sensitive photographs of human remains generally are not accepted for publication in any SAA journal. Requests for waivers of this policy may be submitted to the editor for consideration by the SAA President and members of the Executive Committee. Line drawings or other renderings of human remains may be an acceptable substitute for photographs. In other cases, authors might be asked to present images as online supplemental figures. Authors who wish to include such images are encouraged to contact the editors before submission (Editorial Policy, Information for Authors, and Style Guide for American Antiquity, Latin American Antiquity, and Advances in Archaeological Practice, Section 1.1.9, p. 7, May 2018).

In this case, the importance of the photograph to the intellectual content of the article was deemed critical. President Susan Chandler and the Executive Committee of the SAA recognize that, in different countries and among different populations, there are different opinions and ethical positions surrounding the presentation of such images. This, too, played a role in the decision to publish the figures. The SAA undoubtedly will face similar concerns in the future, and advises authors and readers to be aware of the potential issues and thorough review process that such images require.

4. The earliest date from a Tiwanaku site in the Moquegua valley comes from Omo M16 and has a range of cal AD 653-926 (SHCal13; based on Goldstein 2005:Table 5.2), affirming the arrival of highland groups in Moquegua around the turn of the eighth century.

Submitted February 26, 2017; Revised January 19, 2018; Accepted April 17, 2018 